\title{
Influencing Factors of Mental health of High School Students
}

\author{
Zichen Gu
}

\author{
BASIS International School Shenzhen \\ cecilia200408@icloud.com
}

\begin{abstract}
A group of high school students, especially Chinese high school students with fewer good schools, are under more significant psychological pressure. They often bear higher parental expectations, peer pressure, self-pressure, etc. They must relieve these pressures. Using CFPS data, this article puts forward hypotheses and empirical analysis on the influence factors of peer pressure and parental expectations that affect the psychological status of high school students. Additionally, this paper gives relevant suggestions on how to adjust the mentality of high school students.
\end{abstract}

Keywords: high school students, psychological pressure, current situation, countermeasures

\section{INTRODUCTION}

A survey study shows that 1 out of 5 middle school students in China has considered suicide, and $6.5 \%$ have planned for suicide. Therefore, the psychological problems of high school students and their coping methods have become a hot spot of common concern for students, their families, schools, and all sectors of society. Turkey also predicted excessive pressure on their students [1]. And Many domestic experts and scholars have researched the psychological conditions of high school students. Some experts say that high schools students often face excessive pressure [2]. There are many discussions on the mechanism of the parent-child relationship, peer pressure and other factors on the mental health of high school students at home and abroad. However, there is still a lack of understanding of the particular group of high school students - the systematic study of psychological disorders. Few articles comprehensively consider the impact of the two aspects on the psychology of high school students, and even less empirical analysis using national data.

According to the current research situation, this article explores the impact of parental expectations and peer pressure on the mental health of high school students through the use of China Education Tracking Survey (CFPS) baseline data. According to the existing literature, this paper proposes the following hypotheses.

Hypothesis 1a: The more significant the difference in educational expectations between parents and high school students (parents $>$ high school students), the worse the mental health of high school students.

Hypothesis 1b: The smaller the educational expectation gap between parents and high school students (parents $>$ high school students), the better the mental health.

Hypothesis 2a: The higher the frequency of parentstudent interaction, the better the mental health of high school students.

Hypothesis 2b: The better the relationship between high school students and their parents, the better the mental health of high school students.

Hypothesis 3a: The more competitive pressure from peers in the school, the worse the mental health of high school students.

Hypothesis $3 \mathrm{~b}$ : The more healthy competition among peers in the school, the better the mental health of high school students.

\section{EMPIRICAL ANALYSIS}

\subsection{Data source}

This article uses baseline data from the "China Education Tracking Survey" from the China Survey and Data Center of the Renmin University of China. The survey uses the 2019-2020 school year as the baseline, the first and third grades of high school students as the starting point for the survey, and the regional per capita 
education level and the proportion of the floating population as stratified variables, and randomly selected 20 county-level units across the country A questionnaire survey was conducted among 346 classes in 102 schools. The study subjects include all students, parents, teachers and school principals, and the questionnaires are also divided into the four categories mentioned above. After processing the data and deleting the missing values, the final sample size included in the study was 2080 .

\subsection{Variables}

\subsubsection{Dependent variable}

In the questionnaire part of the students, a mental health scale was designed to ask them, "Did you have the following feelings in the past seven days": "frustration," "depression," "unhappy," "life is meaningless," and "sad." Select the option "Always, "frequently," "sometimes," "rarely," and "never" are assigned values of 1-5 in sequence. We add these five scores to generate a mental health variable as the dependent variable of the article, with a score ranging from 5 to 25 . High score would mean a better mental health [3]. After investigation and testing, the reliability coefficient $\alpha$ of the mental health scale is 0.86 , and it has been used in the study of the mental health of high school students.

\subsubsection{Main independent variables}

The independent variables are divided into two levels: family and school. The independent variables at the family level are:

Generational education gaps: The CEPS's parent questionnaire and student questionnaires set up similar questions to measure their respective educational expectations. The questionnaires convert parents' academic expectations and offspring's educational expectations into corresponding "achievement expectations" and "social status expectations." Subtracting the former from the latter generates a variable of "Inter-generational education expectations difference," which is processed to interpret subsequent models. It is a categorical variable with a value of $0-2$. Take "low parental generation" as the reference group, and its value is 0 , which means that the parental education expectation is lower than that of the offspring; "Parent-child consistent" means that the parent-child generation has the same educational expectation, and its value is 1; "Parental high" indicates that the parental education expectation is higher Child, and its value is 2 .

Parent-child interaction: The CEPS questionnaire contains questions about parent-child interaction, "How often do you and your parents do the following things together." Assign the options "never done," "once per year," "once every six months," "once a month," "once a week," and "more than once a week" to 1-6 and add them up. The interaction scale (reliability coefficient $\alpha$ is 0.77 ) is used to measure parent-child interaction, a continuous variable.

Parent-child relationship: Measured by students' subjective judgment of parent-child relationship in the questionnaire. The relationship with the father and mother is divided into three categories: "not close," "normal," and "very close," which are coded as 1, 2, and 3 , respectively. The sum of the strength of the parentchild relationship is a fixed-distance variable.

The independent variables at the school level include the school's internal environment and atmosphere: The CEPS school questionnaire designed questions about the frequency of school students, teachers and students' destructive behaviors (this scale mainly describes the school's violations of regulations and discipline activities and teachers' unreasonable activities in the past week). The reliability coefficient $\alpha$ is 0.85 , and we use it as an indicator to measure the inner atmosphere of the school.

Competitive pressure behaviors of peer groups in schools: The scale sets up the negative performance of peer competition among high school students (compared with classmates academically, compared with classmates in life, a tense atmosphere between peer learning, etc.), and each question has three answers ( 1 represents no such, two illustrates a few such, 3 represents many such).

The independent variables at the school level are divided into the school's internal environment and atmosphere: The CEPS school questionnaire is designed to question the frequency of destructive behaviors of high school students and teachers in the school. We use it as an indicator of the school's inner atmosphere. The higher the score, the better the school environment.

There are three aspects of control variables divided into individual students, families, and schools. The specific variable description statistics are shown in Table 1.

\section{RESEARCH AND ANALYSIS}

This article uses Stata 13.0 statistical software for data processing. The least-squares method (OLS) linear regression analysis is adopted, and the research is carried out in the form of a nested model. Collinearity analysis was performed on all model results to prevent statistical errors. The variance inflation factor (VIF) of each variable was between $1-3.5$, indicating no collinearity in the independent variables.

The analysis strategy of this article is as follows: First, we successively add parent-child relationship variables (model 1), parent education expectation variables (model 2 ), and parent-child interaction variables (model 3 ) on the basis of the primary control variables. A joint family model is set up on this basis, which incorporates all three variables of parent-child interaction, parent-child 
relationship, and inter-generational education expectations into one model, namely Model 4. Its function is to examine the impact of the three independent variables on the mental health of high school students.
Moreover, based on the primary control variables, two school-level variables are gradually added: the school's internal atmosphere, and the negative behaviors of peer group competition correspond to Model 5, Model 6.

Table 1. Variable description statistics table

\begin{tabular}{|c|c|c|c|c|}
\hline Variable & Mean & standard value & Minimum & Max \\
\hline \multicolumn{5}{|c|}{ Individual size (sample size) (sample size: 13568) } \\
\hline Mental health & 19.65 & 4.02 & 5 & 25 \\
\hline Gender (male=1) & 0.48 & 0.50 & 0 & 1 \\
\hline $\begin{array}{c}\text { Grade (Senior Year } \\
\qquad \text { Two }=1 \text { ) }\end{array}$ & 0.33 & 0.35 & 0 & 1 \\
\hline age & 15.50 & 1.24 & 13 & 19 \\
\hline $\begin{array}{l}\text { Student household } \\
\text { registration } \\
(\text { town }=1)\end{array}$ & 0.43 & 0.50 & 0 & 1 \\
\hline Only child (yes=1) & 0.42 & 0.50 & 0 & 1 \\
\hline Student pressure & 3.03 & 1.10 & 0 & 1 \\
\hline \multicolumn{5}{|c|}{ Family level } \\
\hline $\begin{array}{l}\text { Parent-child } \\
\text { interaction }\end{array}$ & 25.68 & 6.90 & 8 & 40 \\
\hline $\begin{array}{l}\text { Generational } \\
\text { education gap }\end{array}$ & 0.40 & 3.62 & -20 & 16 \\
\hline $\begin{array}{l}\text { Parent-child } \\
\text { relationship }\end{array}$ & 5.32 & 0.95 & 2 & 7 \\
\hline $\begin{array}{l}\text { Family household } \\
\text { registration } \\
(\text { town }=1)\end{array}$ & 0.42 & 0.52 & 0 & 1 \\
\hline $\begin{array}{c}\text { Family economic } \\
\text { status }\end{array}$ & 1.86 & 0.52 & 0 & 1 \\
\hline $\begin{array}{c}\text { Disharmonious } \\
\text { relationship } \\
\text { between parents } \\
\text { (Yes=1) }\end{array}$ & 0.09 & 0.30 & 0 & 1 \\
\hline \multicolumn{5}{|c|}{ School level } \\
\hline $\begin{array}{l}\text { The nature of the } \\
\text { school (public = 1) }\end{array}$ & 0.94 & 0.27 & 0 & 1 \\
\hline School ranking & 2.05 & 0.66 & 1 & 3 \\
\hline $\begin{array}{l}\text { School location } \\
\quad(\text { center }=1)\end{array}$ & 0.39 & 0.47 & 0 & 1 \\
\hline
\end{tabular}




\begin{tabular}{|c|c|c|c|c|}
\hline $\begin{array}{c}\text { Inner atmosphere } \\
\text { of the school }\end{array}$ & 22.32 & 2.48 & 12 & 25 \\
\hline $\begin{array}{c}\text { Competitive } \\
\text { pressure among } \\
\text { peers }\end{array}$ & 6.40 & 1.83 & 1 & 10 \\
\hline
\end{tabular}

Table 2. Estimated results of the OLS regression model for family and school-level variables

\begin{tabular}{|c|c|c|c|c|c|c|}
\hline Variables & $\begin{array}{l}\text { Model } 1 \\
\text { Parent-child } \\
\text { relationship }\end{array}$ & $\begin{array}{c}\text { Model } 2 \\
\text { Generational } \\
\text { education } \\
\text { gap }\end{array}$ & $\begin{array}{c}\text { Model } 3 \\
\text { Parent-child } \\
\text { interaction }\end{array}$ & $\begin{array}{l}\text { Model } 4 \\
\text { Family } \\
\text { union } \\
\text { model }\end{array}$ & $\begin{array}{c}\text { Model } 5 \\
\text { Inner } \\
\text { atmosphere } \\
\text { of the school }\end{array}$ & $\begin{array}{c}\text { Model } 6 \\
\text { Peer } \\
\text { group } \\
\text { negative } \\
\text { behavior }\end{array}$ \\
\hline \multicolumn{7}{|c|}{ Individual level variables } \\
\hline $\begin{array}{l}\text { Parent-child } \\
\text { relationship }\end{array}$ & $0.93^{\star \star *}$ & & & $0.80^{* \star \star}$ & & \\
\hline $\begin{array}{l}\text { Generational } \\
\text { education } \\
\text { gap (highest } \\
\text { parental } \\
\text { generation } \\
\text { as a } \\
\text { reference) }\end{array}$ & & $0.94^{\star \star \star}$ & & & & \\
\hline $\begin{array}{l}\text { Parent-child } \\
\text { agreement }\end{array}$ & & $0.21^{\star \star}$ & & $0.18^{\star \star}$ & & \\
\hline $\begin{array}{l}\text { Parent-child } \\
\text { interaction }\end{array}$ & & $-0.19^{\star \star}$ & & -0.12 & & \\
\hline \multicolumn{7}{|l|}{$\begin{array}{l}\text { Control } \\
\text { variable }\end{array}$} \\
\hline $\begin{array}{l}\text { Gender } \\
\text { (male=1) }\end{array}$ & $0.45^{\star \star *}$ & $0.46^{\star \star \star}$ & $0.43^{* * *}$ & $0.45^{* * *}$ & $0.45^{\star * *}$ & $0.62^{* * \star}$ \\
\hline $\begin{array}{c}\text { Grade } \\
\text { (Senior Year } \\
\text { Two = 1) }\end{array}$ & $-0.20^{\star \star *}$ & $-0.26^{\star \star \star}$ & $-0.26^{\star \star \star}$ & $-0.23^{* * *}$ & $-0.21^{\star}$ & $-0.19 *$ \\
\hline Age & & & & & $-0.21^{\star}$ & $-0.19^{\star}$ \\
\hline $\begin{array}{c}\text { Household } \\
\text { registration } \\
\text { (town=1) }\end{array}$ & $-0.17^{\star * \star}$ & $-0.16^{*}$ & -0.10 & -0.13 & -0.09 & -0.05 \\
\hline $\begin{array}{l}\text { Only child } \\
\text { (yes }=1 \text { ) }\end{array}$ & 0.10 & $0.23^{\star * *}$ & $0.17^{* \star}$ & 0.09 & $0.23^{* * *}$ & 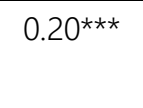 \\
\hline $\begin{array}{l}\text { studying } \\
\text { pressure }\end{array}$ & $-0.51^{\star \star \star}$ & $-0.54^{\star \star \star}$ & $-0.50^{\star \star \star}$ & $-0.48^{\star * *}$ & $-0.54^{\star \star \star}$ & $-0.33^{\star * *}$ \\
\hline $\begin{array}{c}\text { Parents' } \\
\text { education }\end{array}$ & -0.01 & 0.02 & 0.00 & -0.02 & & \\
\hline
\end{tabular}




\begin{tabular}{|c|c|c|c|c|c|c|}
\hline $\begin{array}{c}\text { Family } \\
\text { economic } \\
\text { status }\end{array}$ & $0.33^{* * *}$ & $0.44^{\star * *}$ & $0.40^{* * *}$ & $0.30^{* \star *}$ & $-0.10^{*}$ & -0.09 \\
\hline $\begin{array}{c}\text { Parents } \\
\text { quarrel (yes } \\
=1 \text { ) }\end{array}$ & $-0.188^{\star \star \star}$ & $-2.05^{\star \star \star}$ & $-1.39 * \star \star$ & $-1.43^{\star \star \star}$ & $-2.06^{\star \star \star}$ & $-1.95^{\star \star \star}$ \\
\hline $\begin{array}{l}\text { The nature } \\
\text { of the school } \\
\text { (public = 1) }\end{array}$ & 0.03 & 0.15 & 0.16 & 0.06 & 0.12 & 0.02 \\
\hline $\begin{array}{l}\text { School } \\
\text { location } \\
\text { (center=1) }\end{array}$ & $-0.38^{\star * \star}$ & $-0.40^{* * *}$ & $-0.26^{* * *}$ & $-0.25^{\star \star}$ & $-0.43^{* \star \star}$ & $0.17^{\star \star \star}$ \\
\hline $\begin{array}{l}\text { School } \\
\text { ranking }\end{array}$ & $0.18^{\star * \star}$ & $0.22^{* * *}$ & $0.12^{* \star}$ & $0.09 *$ & $0.24^{\star * *}$ & $0.17^{\star \star \star *}$ \\
\hline $\begin{array}{c}\text { Peer } \\
\text { pressure }\end{array}$ & -0.90 & -0.89 & -0.28 & -0.45 & -0.82 & -0.90 \\
\hline intercept & $19,40^{* \star *}$ & $20,83^{\star \star \star}$ & $16,43^{* * *}$ & $15,65^{\star * *}$ & $20.43^{* * *}$ & $23.65^{\star \star \star *}$ \\
\hline Sample size & 2080 & 2080 & 2080 & 2080 & 2080 & 2080 \\
\hline R party & 0.10 & 0.09 & 0.12 & 0.13 & 0.08 & 0.10 \\
\hline Model fit & & & & & & \\
\hline
\end{tabular}

\section{ANALYSIS RESULT}

\subsection{The influence of family-level variables on the mental health of high school students}

Under the premise of controlling the characteristic values of individuals, families, and schools, a nested model is set up to specifically analyze the impact of parent-child interaction, parent-child relationship, and parental educational expectations on the mental health of high school students. The specific results are shown in Table 2.

Model 1 in Table 2 shows that the better the parentchild relationship, the better the mental health of high school students. In the questionnaire, the subjective parent-child relationship assessment of high school students is a true expression of the personal emotional experience of high school students, so it has good reliability. Therefore, the results of Model 1 verify Hypothesis $1 b$.

Model 2 shows that poor inter-generational education expectations are significantly related to the mental health of high school students. The model results show that the parents and offspring's academic expectations are the same, and 0.25 points can increase high school students' mental health values; from the parent's high results, if the parents' educational expectations are higher than For offspring, the mental health value of high school students dropped by 0.19 points. The results of Model 2 confirm
Hypothesis 2. The results also prove that family Processes Affect Students' Motivation [4].

From the results of Model 3, it is proved that parentchild interaction has a specific effect on the mental health of high school students: the higher the frequency of parent-child interaction, the better the mental health of high school students. So Hypothesis 1a is verified. Table 2 In the family union model, the statistical significance of the parent-child relationship and parent-child interaction variables has not changed, and the coefficient has decreased slightly.

In addition, the control variables of Model 4 partly prove that there are significant gender differences in the mental health of high school students, which is consistent with existing research. The influence of parents' educational expectations is gradually emerging. When high school students' academic expectations are lower than their parents' expectations, the parents' high expectations may constitute additional pressure, making the mental health of high school students relatively poor. The results of Model 2 confirm Hypothesis 2.

\subsection{The impact of school-level variables on high school students}

Table 2 reflects the impact of three variables from the school level on the mental health of high school students. Therefore, the results of Model 5 support Hypothesis 4, that is, the better the internal atmosphere of the school, the better the mental health of high school students. 
From the results of Model 6, peer group activities significantly affect the mental health of high school students. The more competitive pressure of the school peer group, the worse the mental health of high school students, so Hypothesis $3 \mathrm{a}$ and Hypothesis $3 \mathrm{~b}$ were confirmed.

\section{CONCLUSION}

This paper uses the China Education Tracking Survey data to analyze the factors affecting the mental health of high school students. Among them, the focus is on the comprehensive influence mechanism of family and peers on adolescents' mental health. It is found that family social capital, school environment, and peer pressure significantly affect adolescents' mental health.

Therefore, we should actively guide peer competition among high school students to form an atmosphere of mutual help. At the same time, parents should also reduce the pressure on students. It is crucial to pay attention to the differences in communication between boys and girls [3]. Society should also devote more resources to caring for high school students.

\section{REFERENCES}

[1] Fulya Yüksel-ahin. "Predicting Peer Pressure Levels Among Turkish Adolescents." Procedia - Social and Behavioral Sciences 191(2015):1807-1812.

[2] Weissbourd, R. "The Overpressured Student." Educational Leadership 68.8(2011):22-27.

[3] Han, and Jeong-Gyu. "AInfluence of Parents' Academic Achievement Pressure and Overprotective Attitudes on the Test Anxiety of High School Female Students." Asian Journal of

Education 17.3(2016):153-169.

[4] Koutsoulis, M. K., and J. R. Campbell . "Family Processes Affect Students' Motivation, and Science and Math Achievement in Cypriot High Schools." Structural Equation Modeling A Multidisciplinary Journal 8.1(2001):108-127. 